\title{
Innovative Land Arrangement in Combination with Irrigation Methods Improves the Crop and Water Productivity of Rice (Oryza sativa L.) Grown with Okra (Abelmoschus esculentus L.) under Raised and Sunken Bed Systems
}

\author{
Pijush Das ${ }^{1,2}$, Biswajit Pramanick ${ }^{2,3, * \mathbb{D}}$, Subhendu Bikash Goswami ${ }^{2}$, Sagar Maitra ${ }^{4} \mathbb{D}$, Sobhy M. Ibrahim ${ }^{5} \mathbb{D}$, \\ Alison M. Laing ${ }^{6}$ and Akbar Hossain $7, * \mathbb{D}$ \\ 1 School of Agriculture and Allied Sciences, The Neotia University, Kolkata 743368, India; piju1987@gmail.com \\ 2 Department of Agronomy, Bidhan Chandra Krishi Viswavidyalaya, Mohanpur 741252, India; \\ sbg_bckv05@rediffmail.com \\ 3 Department of Agronomy, Rajendra Prasad Central Agricultural University, Pusa 848125, India \\ 4 Department of Agronomy, Centurion University of Technology and Management, \\ Paralakhemundi 761211, India; sagar.maitra@cutm.ac.in \\ 5 Department of Biochemistry, College of Science, King Saud University, P.O. Box 2455, \\ Riyadh 11451, Saudi Arabia; syakout@ksu.edu.sa or sobhy.yakout@gmail.com \\ check for \\ updates \\ Citation: Das, P.; Pramanick, B.; \\ 6 CSIRO Agriculture \& Food, Brisbane 1700, Australia; alison.laing@csiro.au \\ 7 Department of Agronomy, Bangladesh Wheat and Maize Research Institute, Dinajpur 5200, Bangladesh \\ * Correspondence: biswajit@rpcau.ac.in (B.P.); akbarhossainwrc@gmail.com (A.H.)
} Goswami, S.B.; Maitra, S.; Ibrahim, S.M.; Laing, A.M.; Hossain, A. Innovative Land Arrangement in Combination with Irrigation Methods Improves the Crop and Water Productivity of Rice (Oryza sativa L.) Grown with Okra (Abelmoschus esculentus L.) under Raised and Sunken Bed Systems. Agronomy 2021, 11, 2087. https://doi.org/10.3390/ agronomy 11102087

Academic Editor:

Kestutis Romaneckas

Received: 18 September 2021

Accepted: 12 October 2021

Published: 19 October 2021

Publisher's Note: MDPI stays neutral with regard to jurisdictional claims in published maps and institutional affiliations.

Copyright: (C) 2021 by the authors Licensee MDPI, Basel, Switzerland. This article is an open access article distributed under the terms and conditions of the Creative Commons Attribution (CC BY) license (https:/ / creativecommons.org/licenses/by/ $4.0 /)$.

\begin{abstract}
The underground water and water storage reservoirs are rapidly depleting due to nominal recharging by the rainfalls making water a scarce resource for irrigation resulting in poor crop growth and production. Irrigation water application should focus on the proficient use of each drop of water. Water productivity (WP) in agriculture can be improved through crop diversification, proper land and water management techniques. Considering this, a field investigation was carried out during 2013-2014 and 2014-2015 to study the crop response of rice (Oryza sativa L.) + okra (Abelmoschus esculentus L.) system to land configurations and irrigation regimes. Three raised-sunken beds (RSB) having width $(\mathrm{m})$ ratios of 1:3, 2:3, 3:3 and two irrigation schedules viz. continuous standing water (CSW) of $5 \pm 2 \mathrm{~cm}$ depth and alternate wetting and drying (AWD) at $3 \pm 1$ days interval for rice in sunken bed were tested. Rice yield was more (4.36 and $4.89 \mathrm{Mg} \mathrm{ha}^{-1}$ ) under CSW irrigation than AWD irrespective of raised bed width. The highest okra yield was noted by 14.09 and 15.43 $\mathrm{Mg} \mathrm{ha}{ }^{-1}$ with AWD in 1:3 RSB systems, whereas the lowest yield was recorded in CSW 1:3 RSB systems. Rice equivalent yield (REY) was found as the maximum in AWD than CSW irrespective of raised and sunken bed configurations. The AWD in 3:3 RSB systems exhibited the highest WP of 1.02 and $1.01 \mathrm{~kg} \mathrm{~m}^{-3}$ during the first and second year of study, respectively. Wider RSB system of land configuration ratio of $3: 3$ saved about $40-45 \%$ of irrigation water. Such information will help in the planning of an innovative intercropping system of summer rice + okra in the field by changing the land configuration to the raised bed and sunken bed with the AWD irrigation system.
\end{abstract}

Keywords: raised-sunken bed; irrigation; yield; water productivity

\section{Introduction}

Rice (Oryza sativa L.) is one of the most important grain crops for more than $50 \%$ of the world's population, accounting for approximately $20 \%$ of total energy intake and an annual increase of 8-10 million tons is estimated necessary to meet future needs [1,2]. It is the most important crop of India and the second most important crop in the world. Being the staple food for more than $70 \%$ of the Indians, our national food security hinges on the growth and stability of rice production. It is a drought-susceptible crop exhibiting serious deleterious 
effects when exposed to water stress at critical growth stages especially at the reproductive stage [3]. But at the same time, it can adapt to soil water deficit [4]. Again, shortage of water for irrigation is one of the most crucial factors limiting the growth and production of almost all the crops including rice worldwide and the intensity of the issue is aggravating over time $[5,6]$. In contrast with other crops, rice is particularly more sensitive to water stress especially at critical growth stages such as panicle initiation, anthesis, and grain filling $[7,8]$. Production growth of rice was marvelous over 3 decades with the introduction of high yielding varieties, irrigation water, and chemical fertilizers. But productivity has now become stagnated or even declining under exhaustive cropping sequences in irrigated ecosystems. In this critical juncture, rice growers have limited options to increase rice productivity when land and water resource are dwindling and the cost of cultivation is soaring.

Okra (Abelmoschus esculentus L.) is a popular vegetable crop in India. Okra crop is very sensitive to the status of soil moisture, as soil water stress or excess water both limits the plant growth and fruit yield. The crop is grown year-round under varied soil and climatic conditions of the country. India is the world's topmost country covering almost $70 \%$ of global okra production [9]. Farmers of lowland areas generally grow low-yielding and long-duration varieties of rice in the rainy season, and after the harvest of rice, the land remains fallow. Therefore, diversification and intensification of the rice-based cropping system is the need of the hour to enhance productivity and income [10]. The inclusion of vegetables in the rice culture can be one of the alternative land-use systems for higher crop water productivity [11].

The underground water and water storage reservoirs are rapidly depleting due to nominal recharging by the rainfalls and continuous silting in the dams, making water a scarce resource for irrigation. This shortage of water for irrigation is one of the most crucial factors limiting the growth and production of almost all crops worldwide. Therefore, irrigation water application should take the knowledge of the need to secure maximum output for each drop of water in terms of crop yield or to enhance the crop water productivity. Water productivity (WP) in agriculture would be the single most important factor that can be attained through crop diversification (includes crops having high value of WP), efficient land, and water management techniques. Proper land configuration can be adopted for growing summer rice in sunken bed and vegetables in raised beds for the utilization of seepage water from sunken bed rice. A simple land configuration through raised and sunken bed system (RSB) is a useful technology for proper land and water management to increase crop water productivity [12]. Modification in field topography through the construction of alternate raised and sunken bed improves the physical environment, particularly the aeration status of the soil and creates the proper condition for the growth of crops [13]. Water management practices like 'Alternate Wetting and Drying' (AWD) tackle water scarcity in a better way in irrigated rice cultivation and has the potential to contribute to more sustainable and effective water use. AWD is a knowledge-intensive technology as it is based on the insights gained by scientists at IRRI that rice, despite being a semi-aquatic plant, can tolerate reduced water supply without suffering any negative effects. The water level in the rice field can drop down to 10 to $15 \mathrm{~cm}$ below the soil surface without significantly affecting the yield. AWD and non-flooded irrigation have shown promising results in reducing water consumption without a significant effect on rice grain yield [13]. Water productivity in agriculture would be the single most important factor driving water use globally in the future $[13,14]$. The declining ground water table is more pronounced in tube well-commanded irrigation systems of lower Gangetic Plain Regions of India. Concerning the potentialities of the AWD system as well as raised and sunken bed system as mentioned above, the current study was designed with innovative rice plus okra system, where rice was grown in the sunken bed being a water-loving crop and okra was grown in the raised bed.

All the above information leaves a huge scope for designing an innovative land configuration along with irrigation management practices for high-irrigation demanding 
summer rice crops. Keeping all these in the background, the present study aimed at the growing of arable vegetables in the raised bed and wet crop rice in sunken bed to save aquifer water in the tube well commanded lower Gangetic Plain. The novelty of the study was to generate new information about environmentally sustainable land configuration methods along with irrigation for the summer rice + okra system.

\section{Materials and Methods}

\subsection{Experimental Site}

The field experiment was carried out at the Central Research Farm (CRF) of Bidhan Chandra Krishi Viswavidyalaya (BCKV), West Bengal, India in two consecutive winter seasons of 2013-2014 and 2014-2015. The experimental site was situated at $22^{\circ} 58^{\prime} \mathrm{N}$ latitude and $88^{\circ} 29^{\prime} \mathrm{E}$ longitude with an altitude of $9.75 \mathrm{~m}$ above the mean sea level, and topographically the land is medium in slope (Figure 1). The soil of the experimental field is typical of Gangetic alluvium (Inceptisol) type with medium water holding capacity and moderate fertility status. The soil was sandy loam in texture with a $\mathrm{pH}$ of 6.8 , organic carbon of $5.5 \mathrm{~g} \mathrm{~kg}^{-1}$, available nitrogen of $238 \mathrm{~kg} \mathrm{ha}^{-1}$, available P of $14.7 \mathrm{~kg} \mathrm{ha}^{-1}$ and available $\mathrm{K}$ of $145 \mathrm{~kg} \mathrm{ha}^{-1}$. Physical properties of the soil in the root zone depth $(0-90 \mathrm{~cm})$ were as follows: soil moisture tension at field capacity $0.36 \mathrm{~m}^{3} \mathrm{~m}^{-3}$, wilting point $0.16 \mathrm{~m}^{3} \mathrm{~m}^{-3}$, bulk density $1.47 \mathrm{Mg} \mathrm{m}^{-3}$, and hydraulic conductivity $8-12 \mathrm{~mm} \mathrm{~h}^{-1}$. The experimental site belongs to a subtropical humid climate. The summer is hot and the winter is moderate. Pre-monsoon rain is common in the month of April and May (Figure 2).

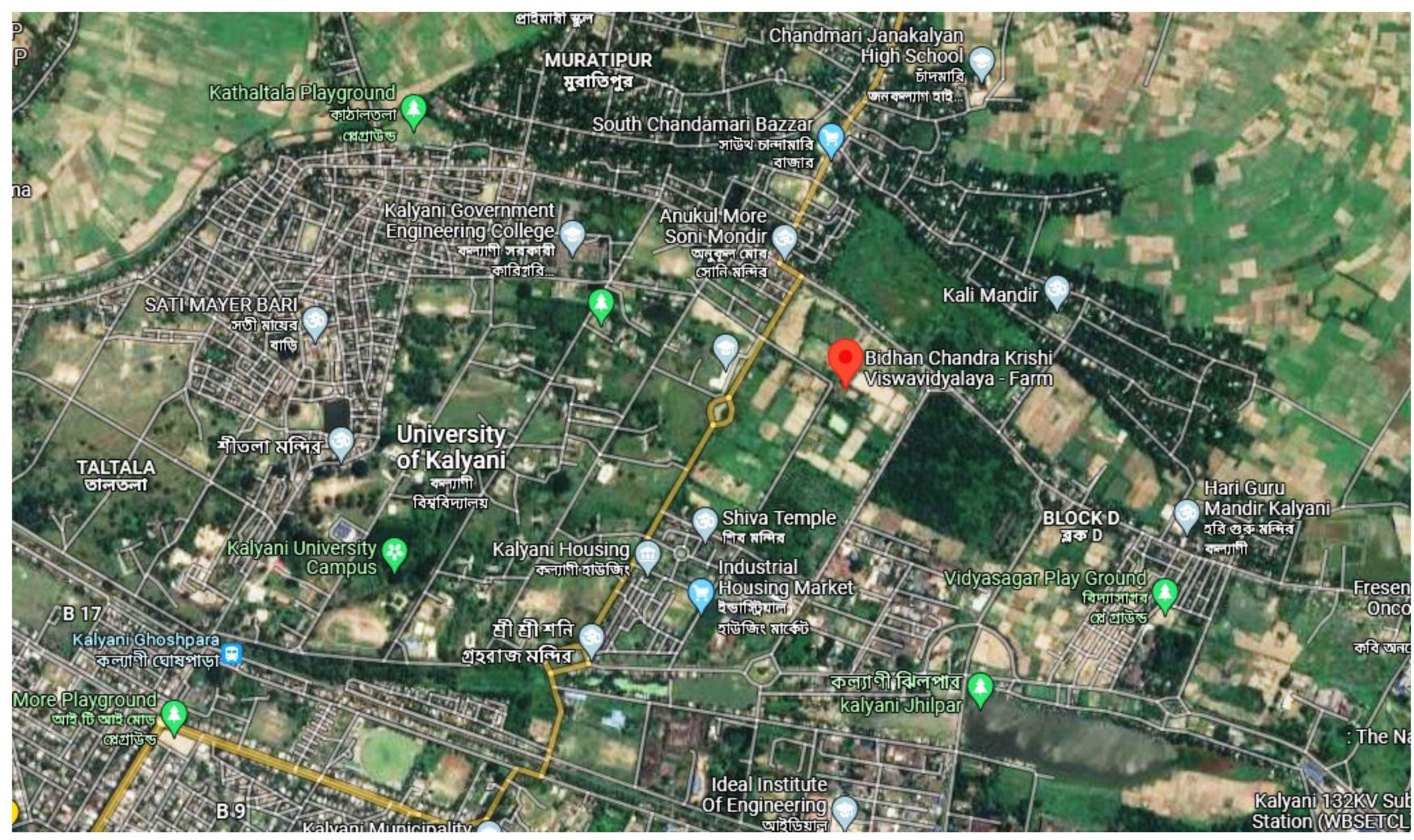

Figure 1. Map of the research farm where the study was conducted. 


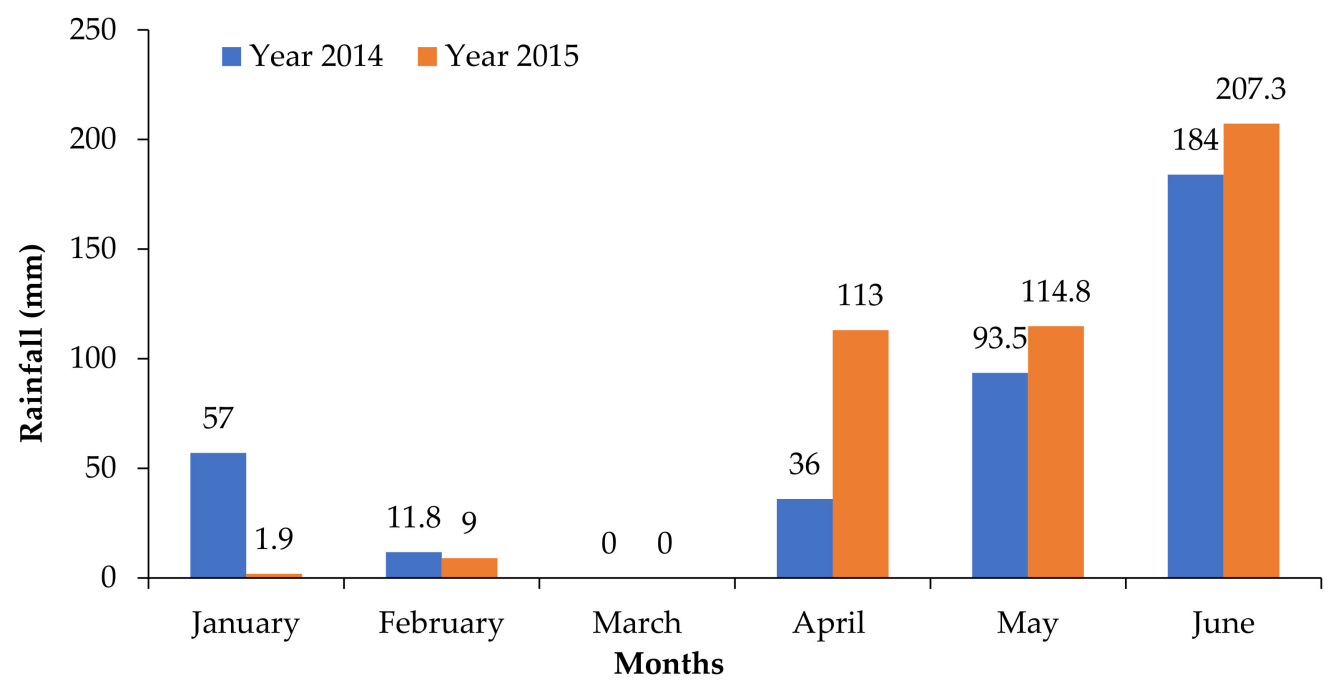

Figure 2. Monthly rainfall distribution pattern during the period of experimentation; values above bars denote the amount of total rainfall $(\mathrm{mm})$.

The normal monsoon of this region breaks in the first week of June. The average annual rainfall is $1500 \mathrm{~mm}$, mostly precipitated during the months of June to September. Monsoon season ceases during October and the cool season sets in November. The meteorological data pertaining to the period of experimentation are given in Table 1.

Table 1. Meteorological data during the experimentation.

\begin{tabular}{|c|c|c|c|c|c|c|c|c|c|c|c|c|}
\hline \multirow{3}{*}{ Months } & \multicolumn{4}{|c|}{ Temperature $\left({ }^{\circ} \mathrm{C}\right)$} & \multicolumn{4}{|c|}{ Relative Humidity (\%) } & \multicolumn{2}{|c|}{ BRS (h d $\left.\mathrm{d}^{-1}\right)$} & \multicolumn{2}{|c|}{$E_{p a n}\left(m m d^{-1}\right)$} \\
\hline & \multicolumn{2}{|c|}{2014} & \multicolumn{2}{|c|}{2015} & \multicolumn{2}{|c|}{2014} & \multicolumn{2}{|c|}{2015} & \multirow{2}{*}{2014} & \multirow[b]{2}{*}{2015} & \multirow[b]{2}{*}{2014} & \multirow[b]{2}{*}{2015} \\
\hline & Max. & Min. & Max. & Min. & Max. & Min. & Max. & Min. & & & & \\
\hline January & $23.5 \pm 0.2$ & $13.21 \pm 0.4$ & $25.1 \pm 0.3$ & $9.97 \pm 0.1$ & $95.6 \pm 1$ & $60.8 \pm 1$ & $93.7 \pm 1$ & $49.0 \pm 2$ & $5.49 \pm 0.05$ & $5.56 \pm 0.04$ & $1.06 \pm 0.01$ & $1.14 \pm 0.01$ \\
\hline February & $28.9 \pm 0.3$ & $14.0 \pm 0.1$ & $29.4 \pm 0.4$ & $13.5 \pm 0.2$ & $90.4 \pm 2$ & $42.9 \pm 1$ & $91.0 \pm 2$ & $44.7 \pm 1$ & $8.71 \pm 0.02$ & $7.60 \pm 0.01$ & $2.09 \pm 0.01$ & $1.99 \pm 0.01$ \\
\hline March & $34.5 \pm 0.2$ & $20.6 \pm 0.3$ & $36.2 \pm 0.2$ & $20.0 \pm 0.3$ & $87.9 \pm 1$ & $36.7 \pm 1$ & $88.5 \pm 1$ & $34.2 \pm 1$ & $8.74 \pm 0.05$ & $7.98 \pm 0.05$ & $3.57 \pm 0.02$ & $3.53 \pm 0.02$ \\
\hline April & $36.1 \pm 0.2$ & $24.2 \pm 0.05$ & $37.6 \pm 0.3$ & $24.2 \pm 0.1$ & $87.4 \pm 3$ & $49.0 \pm 1$ & $88.0 \pm 2$ & $43.4 \pm 3$ & $8.49 \pm 0.03$ & $8.41 \pm 0.04$ & $4.82 \pm 0.02$ & $4.53 \pm 0.02$ \\
\hline May & $36.7 \pm 0.5$ & $26.6 \pm 0.1$ & $34.8 \pm 0.2$ & $25.7 \pm 0.2$ & $90.4 \pm 1$ & $55.6 \pm 2$ & $90.6 \pm 1$ & $68.2 \pm 4$ & $8.39 \pm 0.01$ & $5.22 \pm 0.02$ & $4.38 \pm 0.02$ & $3.42 \pm 0.01$ \\
\hline June & $37.9 \pm 0.3$ & $29.1 \pm 0.0 .5$ & $34.2 \pm 0.3$ & $26.4 \pm 0.1$ & $88.6 \pm 2$ & $56.6 \pm 1$ & $94.1 \pm 3$ & $78.6 \pm 2$ & $4.90 \pm 0.04$ & $4.74 \pm 0.03$ & $3.20 \pm 0.01$ & $2.51 \pm 0.01$ \\
\hline
\end{tabular}

Max.-Maximum; Min.-Minimum; BRS-Bright Sunshine Hour; Epan.-Pan Evaporation; values followed by standard deviation ( \pm ) $(n=10)$.

\subsection{Land Configuration}

The experimental field was ploughed in a criss-cross manner by a tractor-drawn duck foot cultivator initially. Raised bed-sunken bed (RSB) was configured at width (m) ratios of 1:3; 2:3, and 3:3. These ratios clearly depict that the width of the sunken bed was always $3 \mathrm{~m}$, and the widths of the raised beds were, $1 \mathrm{~m}, 2 \mathrm{~m}$, and $3 \mathrm{~m}$ for 1:3, 2:3, and 3:3 ratios, respectively. A $0-10 \mathrm{~cm}$ soil layer was removed to make each sunken bed and deposited on the adjacent raised bed, making the sunken beds $20 \mathrm{~cm}$ deeper than the raised bed. Final ploughing with a power tiller in standing water was carried out twice to make the land well puddled, and then laddering was done to get a uniform surface in sunken beds, and spading was done in the raised beds to get a well-aerated and uniform surface. The whole experimental field was divided into 3 blocks, each of which contained 9 plots. Three irrigation channels were provided along the length of the experimental field in between rows of plots. The width of the irrigation channels were $1 \mathrm{~m}$. An area having $1 \mathrm{~m}$ width was left as a buffer between the sole plots. Rice was grown on the sunken beds irrespective of all the treatments and okra was grown on raised broad beds of different breadth and widths with $20 \mathrm{~cm}$ elevation following the land configuration model (Figure 3). The length of each plot in the RSB system was $6 \mathrm{~m}$. The breadth of all the sole plots for sunken bed was $3 \mathrm{~m}$, and for the raised okra bed three different bed widths of $1 \mathrm{~m}, 2 \mathrm{~m}$, and $3 \mathrm{~m}$ were taken as per the requirement. Land configuration was made in the 1st cropping season and the layout was maintained as such for the next season as well. 


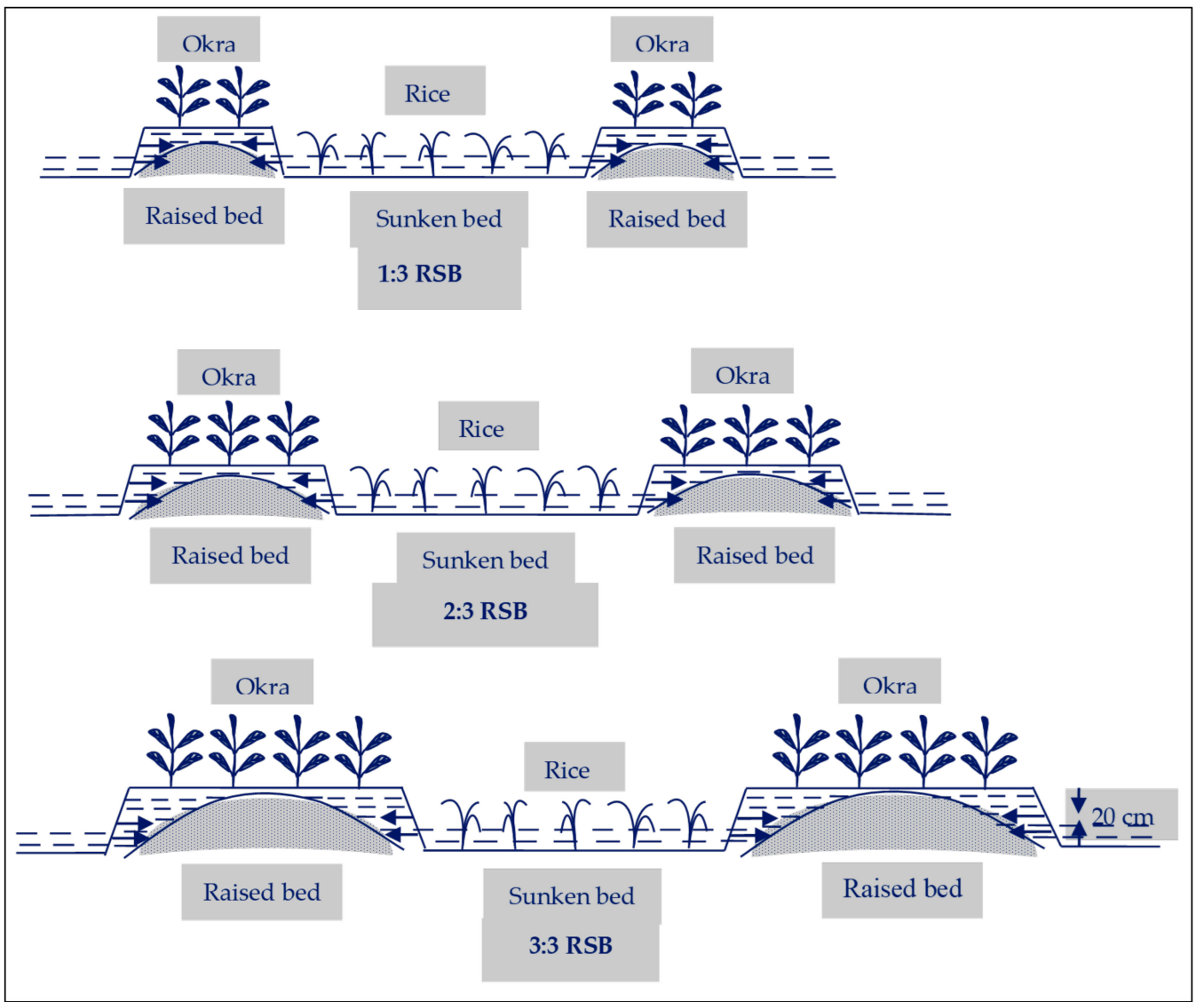

Figure 3. Hydraulics of soil water movement in raised bed from sunken bed (RSB) having different raised bed widths.

\subsection{Irrigation Method}

Two irrigation schedules, namely $\mathrm{I}_{1}$ —continuous standing water (CSW) with standing water of $5 \pm 2 \mathrm{~cm}$ depth and $\mathrm{I}_{2}$-alternate wetting drying (AWD) at $3 \pm 1$ days interval for rice in sunken bed, were taken for this study. Continuous standing water for rice was maintained up to the grain filling stage. Afterwards, the water level in the sunken bed was not maintained. Total numbers of irrigations for CSW in first and second year of study were 19 and 15, respectively, while the numbers were 12 and 9 for AWD during 1st and 2nd year. Depth of irrigation water was $5 \mathrm{~cm}$.

\subsection{Treatment Details}

The field experiment was laid out in randomized block design (RBD) comprising nine treatments with three replications. Thus, there were 27 plots in the experiment. Each plot size for sunken bed rice was $6 \mathrm{~m} \times 3 \mathrm{~m}$ in size, and raised bed okra had varied plot sizes with different bed widths of $1 \mathrm{~m}, 2 \mathrm{~m}$, and $3 \mathrm{~m}$ and a uniform length of $6 \mathrm{~m}$. The plot size for sole okra crop was $6 \mathrm{~m} \times 3 \mathrm{~m}$. A buffer strip of $1 \mathrm{~m}$ was constructed to separate the sole plots both under CSW and AWD irrigation scheduling and also the sole rice AWD plot from the sole okra plot. Treatment details of raised and sunken bed (RSB) with irrigation scheduling are as follows: $\mathrm{T}_{1}-\mathrm{I}_{1} \mathrm{RSB}_{1}$ (1:3) - CSW in $3 \mathrm{~m}$ sunken rice bed with $1 \mathrm{~m}$ raised okra bed; $\mathrm{T}_{2}-\mathrm{I}_{1} \mathrm{RSB}_{2}$ (2:3) - CSW in $3 \mathrm{~m}$ sunken rice bed with $2 \mathrm{~m}$ raised okra bed; $\mathrm{T}_{3}-\mathrm{I}_{1}$ $\mathrm{RSB}_{3}$ (3:3) - CSW in $3 \mathrm{~m}$ sunken rice bed with $3 \mathrm{~m}$ raised okra bed; $\mathrm{T}_{4}-\mathrm{I}_{2} \mathrm{RSB}_{1}$ (1:3) - AWD in $3 \mathrm{~m}$ sunken rice bed with $1 \mathrm{~m}$ raised okra bed; $\mathrm{T}_{5}-\mathrm{I}_{2} \mathrm{RSB}_{2}$ (2:3)-AWD in $3 \mathrm{~m}$ sunken rice bed with $2 \mathrm{~m}$ raised okra bed; $\mathrm{T}_{6}-\mathrm{I}_{2} \mathrm{RSB}_{3}(3: 3)-\mathrm{AWD}$ in $3 \mathrm{~m}$ sunken rice bed with $3 \mathrm{~m}$ raised okra bed; $\mathrm{T}_{7}-\mathrm{I}_{1}$ Sole rice with $\mathrm{CSW} ; \mathrm{T}_{8}-\mathrm{I}_{2}$ Sole rice with $\mathrm{AWD}$ and $\mathrm{T}_{9}-$ Sole okra (SO at IW/CPE ratio of 1.0). IW and CPE denote irrigation water and cumulative pan evaporation, respectively. IW/CPE ratio is a climatological approach for scheduling 
irrigation. The amount of IW was $5 \mathrm{~cm}$ for this study. IW/CPE ratio was 1 for $T_{9}$. It indicates that when the CPE value reaches $5 \mathrm{~cm}$, then the crop must be irrigated. In the case of sowing sole okra and rice, the flat sowing method was followed.

\subsection{Crop Establishment}

Crops were raised with standard agronomy practices in raised and sunken beds. Rice (variety-IET 4786) seedlings were raised by wet bed method and transplanted on the 1st week of February when the age of the seedlings was 45 days. Okra (variety-Hybrid Syngenta 152) was sown one week before the transplanting of rice. Straight row planting at 2-3 cm depth was done for rice at a spacing of $20 \mathrm{~cm} \times 15 \mathrm{~cm}$, taking 3-4 seedlings hill ${ }^{-1}$ with the help of a rope marker in all the sunken beds. The rice seedlings were planted in the North-South direction. Okra seeds were sown on the raised bed at a spacing of $50 \mathrm{~cm} \times 50 \mathrm{~cm}$. Gap filling in rice and thinning in okra was done to obtain optimum plant population in the field. A recommended dose of $120 \mathrm{~kg} \mathrm{~N}, 60 \mathrm{~kg} \mathrm{P}$, and $60 \mathrm{~kg} \mathrm{~K}$ for 1 ha was applied to the sunken bed rice crop during both the year of experimentation. $25 \%$ of $\mathrm{N}$, full doses of $\mathrm{P}$, and half of $\mathrm{K}$ were applied as basal during final land preparation. The first top dressing of $50 \% \mathrm{~N}$ at 25 days after transplanting (DAT) and the second top dressing of remaining $25 \%$ of $\mathrm{N}$ and half $\mathrm{K}$ was done at 55 DAT. In the raised bed, N:P:K dose for okra was 120:60:100 $\mathrm{kg} \mathrm{ha}^{-1}$. $25 \%$ of $\mathrm{N}, 50 \%$ of $\mathrm{P}$, and $50 \% \mathrm{~K}$ were applied as basal after layout preparation. The first top dressing of $50 \% \mathrm{~N}, 50 \% \mathrm{P}$, and $50 \% \mathrm{~K}$ was done at 25 days after sowing (DAS) and the second top dressing of remaining $25 \%$ of $\mathrm{N}$ was made at 45 DAS. For effective control of weeds in sunken bed plots, Ambica paddy weeder (Ambica Engineering Works Pvt. Ltd., Talaja, India) was operated between rows rice plants in both directions. Manual hand weeding was done in the respective plots of raised okra bed. Plant protection measures were taken at subsequent growth stages with Chlorpyriphos $20 \% \mathrm{EC}$ at $2.5 \mathrm{~mL} \mathrm{~L}^{-1}$ to control yellow stem borer (Scirpophaga incertulas Walker) infestation in the rice plots. Rice was harvested during the 2nd week of May and plucking of okra fruits started from 3rd week of March and continued up to the end of May for both years.

\subsection{Wateruse, Productivity and Savings}

Water use by the rice crop was calculated using the formula given by Singh et al. [6] and Pereira [15]: Total water use by crop (ET) = Irrigation water supplied (I) + Effective rainfall received (ER) + Capillary rise $(C)+$ Water contribution from the soil profile $(\Delta S W)$.

The amount of irrigation water applied in each sunken bed rice plot starting from transplanting to maturity of crop was determined volumetrically, and the total amount of applied irrigation water was worked out from the number of irrigation multiplied by the depth of irrigation. The measurement of effective rainfall was done by the balance sheet method, i.e., effective rainfall $(E R)=$ Total rainfall $(P)-$ Runoff $(R)-$ Evaporation $(E)-$ Deep percolation (D). Rainfall-runoff and deep percolation losses of water from the field were considered zero for the dry season of both the year of experimentation, and no evaporation loss occurred due to full groundcover by the crop foliage during that period. The capillary rise was presumed to be negligible because of the lower depth of the groundwater table $(<3 \mathrm{~m})$.

Water productivity $(\mathrm{Wp})$ was expressed in physical terms $\left(\mathrm{kg} \mathrm{m}^{-3}\right)$ following the formula given by Kijne et al. [16]:

$$
\mathrm{Wp}=\frac{\text { Yield }}{\text { Water use }}
$$

In the raised bed of okra plot, soil samples were collected from the centre and both edges of bed before and after irrigation to the sunken rice bed. Each time soil samples were collected from different depths $(0-30,30-60$, and $60-90 \mathrm{~cm})$ with the help of soil auger and kept in an aluminum moisture box. The soil sample was dried in hot air oven at $105^{\circ} \mathrm{C}$ 
for $72 \mathrm{~h}$. The dry weight of the sample with the box was then recorded and moisture percentage was computed by gravimetric method.

The soil moisture content was determined as per the following equation given by Reddy [17]:

$$
\text { Soil water content }(\text { depth basis })=\mathrm{Pd} \times \mathrm{BD} \times \text { depth of soil }(\mathrm{cm})
$$

where, Pd is moisture percentage on a weight basis, BD is the bulk density $\left(\mathrm{g} \mathrm{cm}^{-3}\right)$.

Water use in the system was determined proportionally as per the different raised bed width ratios considering the amount of water applied in sole plots of rice crop. Subsequently, water-saving in the system was computed by subtracting the amount of water used in the system from the amount of water applied through irrigation in sole rice plots, and the percentage of water-saving was calculated accordingly.

\subsection{Statistical Analysis}

Data collected from the field experiment was subjected to statistical analysis appropriate to the design following Gomez and Gomez [18]. One-way analysis of variance (ANOVA) was used. Statistical significance of different treatments was calculated following least square difference (LSD, $p=0.05$ ) test using analysis of variance in Randomized Block Design as per Fisher's F-test using the statistical software SPSS v.19 (SPSS Inc., IBM, Chicago, IL, USA). All the graphs were prepared using Microsoft Excel software.

\section{Results and Discussion}

\subsection{Water Use}

\subsubsection{Water Supply in Rice}

The irrigation water supply in sunken bed rice crop varied depending upon the irrigation scheduling ranging from CSW to AWD and the land configuration of raisedsunken bed ranging from 1:3 to 3:3 (Table 2).

Table 2. Irrigation water use of summer rice and okra as influenced by land configuration and water management practices.

\begin{tabular}{|c|c|c|c|c|c|c|c|c|}
\hline \multirow{3}{*}{ Treatment } & \multicolumn{4}{|c|}{ Water Use in Rice/Okra } & \multirow{2}{*}{\multicolumn{2}{|c|}{$\begin{array}{l}\text { Seepage Gain } \\
\text { in Okra }(\mathrm{mm})\end{array}$}} & \multirow{2}{*}{\multicolumn{2}{|c|}{$\begin{array}{l}\text { Water Savings in the } \\
\text { System }(\%)\end{array}$}} \\
\hline & \multicolumn{2}{|c|}{ I (mm) } & \multicolumn{2}{|c|}{$\mathrm{I}+\mathrm{P}(\mathrm{mm})$} & & & & \\
\hline & $2013-2014$ & 2014-2015 & 2013-2014 & 2014-2015 & 2013-2014 & 2014-2015 & 2013-2014 & 2014-2015 \\
\hline $\mathrm{T}_{1}: \mathrm{I}_{1} \mathrm{RSB}_{1}(1: 3)$ & 1088 & 1013 & 1218 & 1214 & 195.8 & 179.4 & 22.9 & 21.7 \\
\hline $\mathrm{T}_{2}: \mathrm{I}_{1} \operatorname{RSB}_{2}(2: 3)$ & 870 & 810 & 1000 & 1011 & 156.1 & 147.3 & 36.7 & 34.8 \\
\hline $\mathrm{T}_{3}: \mathrm{I}_{1} \operatorname{RSB}_{3}(3: 3)$ & 725 & 675 & 855 & 876 & 138.4 & 137.9 & 45.9 & 43.5 \\
\hline $\mathrm{T}_{4}: \mathrm{I}_{2} \operatorname{RSB}_{1}(1: 3)$ & 825 & 788 & 956 & 989 & 114.3 & 115.7 & 22.3 & 20.9 \\
\hline $\mathrm{T}_{5}: \mathrm{I}_{2} \operatorname{RSB}_{2}(2: 3)$ & 660 & 630 & 790 & 831 & 81.2 & 89.7 & 35.8 & 33.6 \\
\hline $\mathrm{T}_{6}: \mathrm{I}_{2} \operatorname{RSB}_{3}(3: 3)$ & 550 & 525 & 680 & 726 & 28.3 & 45.5 & 44.7 & 41.9 \\
\hline $\mathrm{T}_{7}: \mathrm{I}_{1}$ Sole rice & 1450 & 1350 & 1580 & 1551 & - & - & - & - \\
\hline $\mathrm{T}_{8}: \mathrm{I}_{2}$ Sole rice & 1100 & 1050 & 1230 & 1251 & - & - & - & - \\
\hline $\mathrm{T}_{9}$ : Sole okra * & 200 & 200 & 330 & 401 & - & - & - & - \\
\hline F-test ${ }_{0.05}$ & $* *$ & $* *$ & $* *$ & $* *$ & $* *$ & $* *$ & & \\
\hline
\end{tabular}

** denotes significant at $1 \%$ level of probability; I-Irrigation, $\mathrm{P}$-Effective rainfall; * Irrigation was made on IW/CPE=1.0 (4 irrigations); $\mathrm{I}_{1}$ $\mathrm{RSB}_{1}$ (1:3) — continuous standing water (CSW) in $3 \mathrm{~m}$ sunken rice bed with $1 \mathrm{~m}$ raised okra bed; $\mathrm{I}_{1} \mathrm{RSB}_{2}(2: 3)$-CSW in $3 \mathrm{~m}$ sunken rice bed with $2 \mathrm{~m}$ raised okra bed; $\mathrm{I}_{1} \mathrm{RSB}_{3}$ (3:3) —CSW in $3 \mathrm{~m}$ sunken rice bed with $3 \mathrm{~m}$ raised okra bed; $\mathrm{I}_{2} \mathrm{RSB}_{1}$ (1:3) —alternate wetting and drying (AWD) in $3 \mathrm{~m}$ sunken rice bed with $1 \mathrm{~m}$ raised okra bed; $\mathrm{I}_{2} \mathrm{RSB}_{2}(2: 3)$ - AWD in $3 \mathrm{~m}$ sunken rice bed with $2 \mathrm{~m}$ raised okra bed; $\mathrm{I}_{2}$ RSB 3 (3:3) - AWD in $3 \mathrm{~m}$ sunken rice bed with $3 \mathrm{~m}$ raised okra bed; $\mathrm{I}_{1}$ Sole rice with CSW; $\mathrm{I}_{2}$ Sole rice with AWD and Sole okra (SO at IW/CPE ratio of 1.0).

Irrigation water requirements for rice following CSW and AWD were 1350-1450 mm and $1050-1100 \mathrm{~mm}$ respectively. The amount of effective rainfall varied from 129.5 to $201.2 \mathrm{~mm}$ but it was received at the later growth stages of the crop during both the experimental years (Figure 4). 


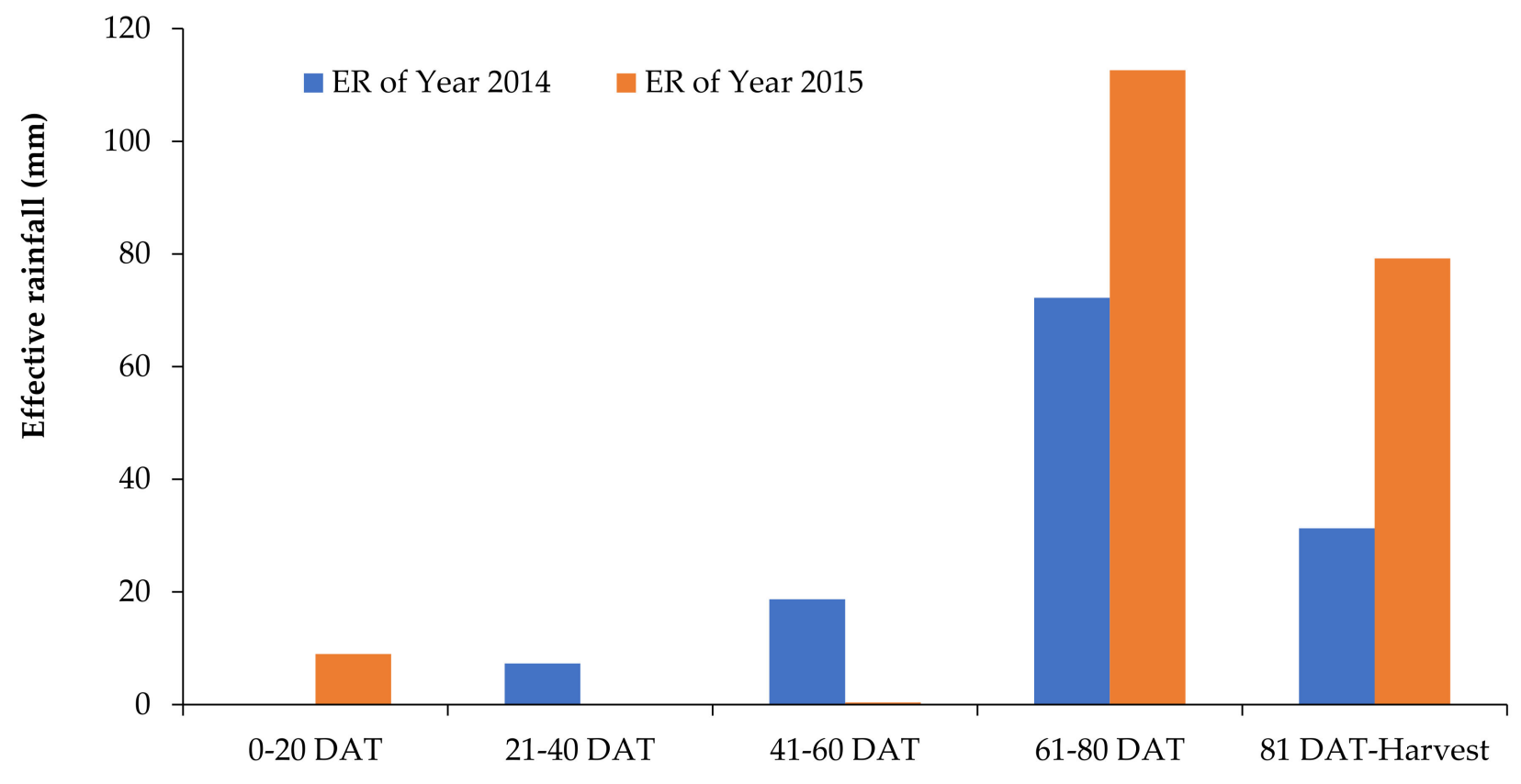

Crop growth stages

Figure 4. Crop growth stage-wise effective rainfall during 2014 and 2015; ER: Effective rainfall (mm); DAT: Days after transplanting.

The least irrigation water use of 525-550 mm was noted in RSB 3:3 with AWD irrigation scheduling, and the highest water use of 1013-1088 mm was recorded in RSB 1:3 under CSW. Total water use was maximum under sole rice grown with CSW $(1551-1580 \mathrm{~mm})$ followed by sole rice grown with AWD (1230-1251 mm) during both the years of experimentation. CSW irrigation scheduling required more irrigation water about $31.82 \%$ and $28.57 \%$ over AWD irrigation scheduling under sole crop during the first and second year, respectively. On the other hand, AWD recorded 22.21 to $24.17 \%$ less irrigation water use over CSW under the RSB land configuration. Adoption of land configuration reduced the total water requirement for rice by 21.72 to $45.88 \%$ both in AWD and CSW irrigation schedules. AWD recorded 20.47 to $21.0 \%$ and 17.12 to $18.53 \%$ less water requirement in terms of total water use with different raised bed width ratio over CSW during both the years of study. This might be attributed with the reduced depth of standing water under AWD irrigation scheduling that lowered the seepage and percolation loss of water from the sunken beds. $\mathrm{Li}$ and Barker [19] also observed reduced irrigation water requirements under the AWD practice. Maintaining a very thin water layer through AWD can reduce the amount of water applied to the field by $40-70 \%$ compared with the traditional practice of continuous shallow submergence [20].

\subsubsection{Seepage Gain in Okra}

Okra crop grown in different raised bed widths was not given irrigation but received seepage water from sunken bed rice (Table 2). Seepage gain in okra varied depending upon the water regime (CSW and AWD) created in the sunken bed and the bed width of the raised bed $(1,2$, and $3 \mathrm{~m})$. The edge of the raised bed adjacent to the sunken bed received more moisture through seepage gain as compared to the middle part of the raised bed. Okra crop was grown in the narrow bed $(1 \mathrm{~m})$ gained more amount of water through seepage than the crop grown in broader beds $(2$ and $3 \mathrm{~m}$ ) under both AWD and CSW irrigation scheduling. The highest seepage water gain of 179.4-195.8 $\mathrm{mm}$ was recorded with $1 \mathrm{~m}$ bed width under CSW water regime in rice but the least seepage gain of $28.3-45.5 \mathrm{~mm}$ was noted in a raised bed of $3 \mathrm{~m}$ width (RSB 3:3) when sunken bed rice crop was under AWD. This may be due to the continuous supply of water to the adjacent sunken bed of rice, 
which gets transmitted through seepage to the okra plot grown under the CSW irrigation regime [21]. There was no seepage gain by the sole okra crop. It was grown in the flat-bed and received about $200 \mathrm{~mm}$ of water through 4 irrigations based on IW/CPE ratio 1.0. Sole okra crop received the highest amount of water supply to the extent of 330 and $401 \mathrm{~mm}$ during 2013-2014 and 2014-2015, respectively.

\subsubsection{Water Savings}

Raised bed land configuration of different bed width ratios saved about 22.9 to $45.9 \%$ and 21.7 to $43.5 \%$ of irrigation water under CSW irrigation scheduling and about 22.3 to $44.7 \%$ and 20.9 to $41.9 \%$ of irrigation water under AWD over sole rice during 2013-2014 and 2014-2015, respectively (Table 2). Sole rice under the AWD water regime saved about $22.2 \%$ and 19.3\% more water than sole rice CSW during 2013-2014 and 2014-2015, respectively. Water saved by the system was about 20.9 to $44.7 \%$ over the sole cropping. Wider bed widths (RSB 3:3 and 2:3) recorded more water savings than the narrow bed widths (RSB 1:3) irrespective of irrigation scheduling. The water ceased more rapidly from the sunken rice beds under AWD, which allowed the surface soil layer to dry away relatively in less time and stored more of the rainwater that resulted in saving of irrigation water. It was also reported that irrigation applied 4 days after the subsidence of standing flood water in fields following AWD saved 42 to $45 \%$ water without significant reduction in rice grain yields [21]. Keeping the soil saturated or following AWD irrigation practice in Sindh (Pakistan) saved water without significant yield loss of rice [22].

\subsection{Crop Performances}

Crop performances of okra and rice were grown in the RSB system were significantly influenced by CSW and AWD irrigation in rice and soil moisture availability in okra (Table 3).

Table 3. Crop yield and water productivity (WP) of summer rice as influenced by land configuration and water management practices.

\begin{tabular}{|c|c|c|c|c|c|c|c|c|}
\hline \multirow{3}{*}{ Treatment } & \multicolumn{6}{|c|}{ Crop Yield (Mg ha $\left.{ }^{-1}\right)$} & \multirow{2}{*}{\multicolumn{2}{|c|}{$\begin{array}{c}\text { WP } \\
\left(\mathrm{kg} \mathrm{m}^{-3}\right)\end{array}$}} \\
\hline & \multicolumn{2}{|c|}{ Okra } & \multicolumn{2}{|c|}{ Rice } & \multicolumn{2}{|c|}{ REY } & & \\
\hline & 2013-2014 & 2014-2015 & 2013-2014 & 2014-2015 & 2013-2014 & 2014-2015 & 2013-2014 & 2014-2015 \\
\hline $\mathrm{T}_{1}: \mathrm{I}_{1} \mathrm{RSB}_{1}(1: 3)$ & $9.42 \pm 1.0^{c}$ & $10.34 \pm 1.1^{\mathrm{d}}$ & $4.36 \pm 0.21^{\mathrm{a}}$ & $4.89 \pm 0.17^{\mathrm{a}}$ & $5.67 \pm 1.09^{c}$ & $6.39 \pm 1.11^{b}$ & $0.47 \pm 0.03$ & $0.53 \pm 0.05$ \\
\hline $\mathrm{T}_{2}: \mathrm{I}_{1} \mathrm{RSB}_{2}(2: 3)$ & $9.44 \pm 0.7^{c}$ & $11.15 \pm 2.1^{c}$ & $3.92 \pm 0.23^{b}$ & $4.22 \pm 0.53^{b}$ & $6.02 \pm 1.12 \mathrm{bc}$ & $6.72 \pm 1.18^{b}$ & $0.60 \pm 0.01$ & $0.67 \pm 0.01$ \\
\hline $\mathrm{T}_{3}: \mathrm{I}_{1} \mathrm{RSB}_{3}(3: 3)$ & $12.16 \pm 1.2^{b}$ & $14.05 \pm 0.9^{b}$ & $3.43 \pm 0.19^{c}$ & $3.56 \pm 0.25^{\mathrm{cd}}$ & $6.82 \pm 1.15^{\mathrm{a}}$ & $7.49 \pm 1.09^{a}$ & $0.79 \pm 0.04$ & $0.85 \pm 0.04$ \\
\hline $\mathrm{T}_{4}: \mathrm{I}_{2} \mathrm{RSB}_{1}(1: 3)$ & $14.09 \pm 2.3^{\mathrm{a}}$ & $15.43 \pm 1.0^{\mathrm{a}}$ & $3.78 \pm 0.09^{b}$ & $3.95 \pm 0.22^{b c}$ & $5.74 \pm 1.17^{c}$ & $6.11 \pm 1.09^{c}$ & $0.60 \pm 0.05$ & $0.62 \pm 0.01$ \\
\hline $\mathrm{T}_{5}: \mathrm{I}_{2} \mathrm{RSB}_{2}(2: 3)$ & $13.32 \pm 2.0^{\mathrm{a}}$ & $14.52 \pm 0.9^{b}$ & $3.34 \pm 0.15^{c}$ & $3.50 \pm 0.74^{\mathrm{cd}}$ & $6.30 \pm 1.09^{b}$ & $6.75 \pm 1.08^{b}$ & $0.80 \pm 0.01$ & $0.81 \pm 0.02$ \\
\hline $\mathrm{T}_{6}: \mathrm{I}_{2} \mathrm{RSB}_{3}(3: 3)$ & $13.62 \pm 1.8^{\mathrm{a}}$ & $14.49 \pm 0.7^{b}$ & $3.12 \pm 0.91^{\mathrm{d}}$ & $3.27 \pm 0.09^{d}$ & $6.91 \pm 1.08^{\mathrm{a}}$ & $7.33 \pm 1.31^{\mathrm{a}}$ & $1.02 \pm 0.02$ & $1.01 \pm 0.05$ \\
\hline $\mathrm{T}_{7}: \mathrm{I}_{1}$ Sole rice & - & - & $4.23 \pm 0.55^{\mathrm{a}}$ & $4.24 \pm 0.08^{b}$ & $4.23 \pm 1.09^{\mathrm{d}}$ & $4.24 \pm 1.05^{\mathrm{d}}$ & $0.27 \pm 0.04$ & $0.27 \pm 0.01$ \\
\hline $\mathrm{T}_{8}: \mathrm{I}_{2}$ Sole rice & - & - & $3.46 \pm 0.21^{\mathrm{c}}$ & $3.63 \pm 0.23^{\mathrm{cd}}$ & $3.46 \pm 1.05^{\mathrm{e}}$ & $3.63 \pm 1.15^{\mathrm{e}}$ & $0.28 \pm 0.01$ & $0.29 \pm 0.01$ \\
\hline $\mathrm{T}_{9}$ : Sole okra * & $10.42 \pm 1.0^{c}$ & $10.40 \pm 1.0^{\mathrm{d}}$ & - & - & $5.79 \pm 1.22^{\mathrm{c}}$ & $5.78 \pm 1.11^{\mathrm{c}}$ & $16.70 \pm 2.0$ & $16.5 \pm 1.3$ \\
\hline F-test & $* *$ & $* *$ & $* *$ & $* *$ & $* *$ & $* *$ & & \\
\hline $\operatorname{LSD}(p \leq 0.05)$ & 1.09 & 0.83 & 0.16 & 0.48 & 0.37 & 0.40 & - & - \\
\hline
\end{tabular}

** significant at $1 \%$ level of probability; * Irrigation was made on IW/CPE=1.0 (4 irrigations); REY-Rice equivalent yield was calculated on sale price of okra and rice of Indian rupee (INR) 10 and $18 \mathrm{~kg}^{-1}$, respectively for both the years; values followed by the standard deviation $( \pm)(n=3)$; Treatment details are listed in the footnote of Table 2; different alphabets followed by mean values denote statistical significance at $p \leq 0.05$, otherwise at-par.

Rice grown in plots with 1:3 bed width ratio under CSW recorded the maximum yield of 4.36 and $4.89 \mathrm{Mg} \mathrm{ha}^{-1}$ as compared to rice grown in other two-bed width ratios, i.e., 2:3 and 3:3 during 2013-2014 and 2014-2015, respectively. It was statistically at par with the yield of sole rice under CSW. Rice grain yield in sunken beds with 1:3 bed width ratio was $13.67-15.34 \%$ higher than sole rice under CSW. In sunken bed, rice yield was more under CSW than AWD irrespective of raised bed width. The higher grain yields in CSW during both the dry season of 2013-2014 and 2014-2015 are attributed to higher numbers of filled grains panicle ${ }^{-1}$, higher panicle weight, and test weight coupled with lower chaffy grain percentage as compared to AWD water regimes [23]. The increased grain yield in CSW 
might also be attributed to higher nutrient uptake by the plants (particularly $\mathrm{N}$ and $\mathrm{P}$ ) as compared with AWD irrigation scheduling [24].

In the raised bed, the yield of okra varied with the change of bed width and water supply. Okra grown in 1:3 RSB system recorded the highest yield of 14.09 and $15.43 \mathrm{Mg} \mathrm{ha}^{-1}$ with AWD irrigation scheduling in rice but the least okra yield (9.42 and $10.34 \mathrm{Mg} \mathrm{ha}^{-1}$ ) was recorded in the same 1:3 RSB system while CSW irrigation schedule was followed in rice during 1st and 2nd year of study. This yield reduction was to the tune of 33.14 to $50.90 \%$ due to a change of irrigation scheduling in rice from CSW to AWD. This result might be attributed to the variation in the soil water availability to the root zone of okra as reported by Sharma [12]. In the AWD irrigation regime, narrow raised bed $(1 \mathrm{~m})$ received more seepage water than wider raised beds ( 2 and $3 \mathrm{~m}$ ), on the contrary, in CSW irrigation okra grown in wider beds ( 3 and $2 \mathrm{~m}$ ) responded better than $1 \mathrm{~m}$ bed as okra was susceptible to water-logging or more water in the root zone.

The RSB land configuration resulted in significant improvement of system production over rice sole cropping through crop diversification and better irrigation water use in the system. Rice equivalent yield (REY) was noted maximum in AWD than CSW irrespective of raised and sunken bed configurations during the first year, while CSW recorded better as compared to AWD during the second year of study. Wider $(3 \mathrm{~m})$ raised bed width gave higher REY due to higher yields of okra to the tune of 9.68 to $20.38 \%$ and 8.59 to $19.97 \%$ over 1 and $2 \mathrm{~m}$ beds under AWD irrigation treatment and the increase was about 19.34 and 26.82\% more over sole okra crop during 2013-2014 and 2014-2015, respectively. Results revealed that the RSB system following rice-tomato/garden pea cropping system gave the highest REY and production efficiency followed by rice-potato/garden pea system, lowest being in rice mono-cropping [25]. Higher REY from RSB land configuration over sole cropping was due to the inclusion of high-value crops like vegetables in the system. Increased paddy and pointed gourd yield under the RSB technology were also reported by Das et al. [26].

\subsection{Water Productivity}

Water productivity (WP) of summer rice and okra as a whole in the system was considerably influenced by water supply levels and raised bed width ratio. RSB (3:3) with AWD irrigation dry regime recorded higher system water productivity value of 1.02 and $1.01 \mathrm{~kg} \mathrm{~m}^{-3}$ water in terms of total water supply (TWS) including rainfall and the increase was to the tune of 27.66 to $29.11 \%$ and 16.98 to $18.82 \%$ over CSW wetted regime in both the growing seasons (Table 3). It was reported that the AWD technique of irrigation increases the water-productivity remarkably at the farm level $[27,28]$. This increased system WP was possible due to the inclusion of okra having a high value of WP $\left(16.5-17.0 \mathrm{~kg} \mathrm{~m}^{-3}\right)$. Higher WP under RSB was mainly due to the inclusion of vegetables having high production potential as compared to rice [29]. An increase in raised bed width increased the dryness in the root zone as a result WP of okra attained higher values. The least system water productivity value of $0.47-0.53 \mathrm{~kg} \mathrm{~m}^{-3}$ was recorded in narrow raised bed RSB (1:3) with the CSW water regime. The WP value of sole rice was very low $\left(0.27-0.29 \mathrm{~kg} \mathrm{~m}^{-3}\right)$. The RSB system recorded higher WP, to the tune of $53.2-72.5 \%$ and $42.6-68.2 \%$, over sole rice crops both under the AWD and CSW irrigation scheduling. This might be attributed to the better utilization of water in the system throughout the crop growing period as compared to sole rice under AWD and CSW water regimes. A moderate relationship between total water supply (TWS) and productivity of rice was achieved under different irrigation regimes and land configurations (Figure 5). 


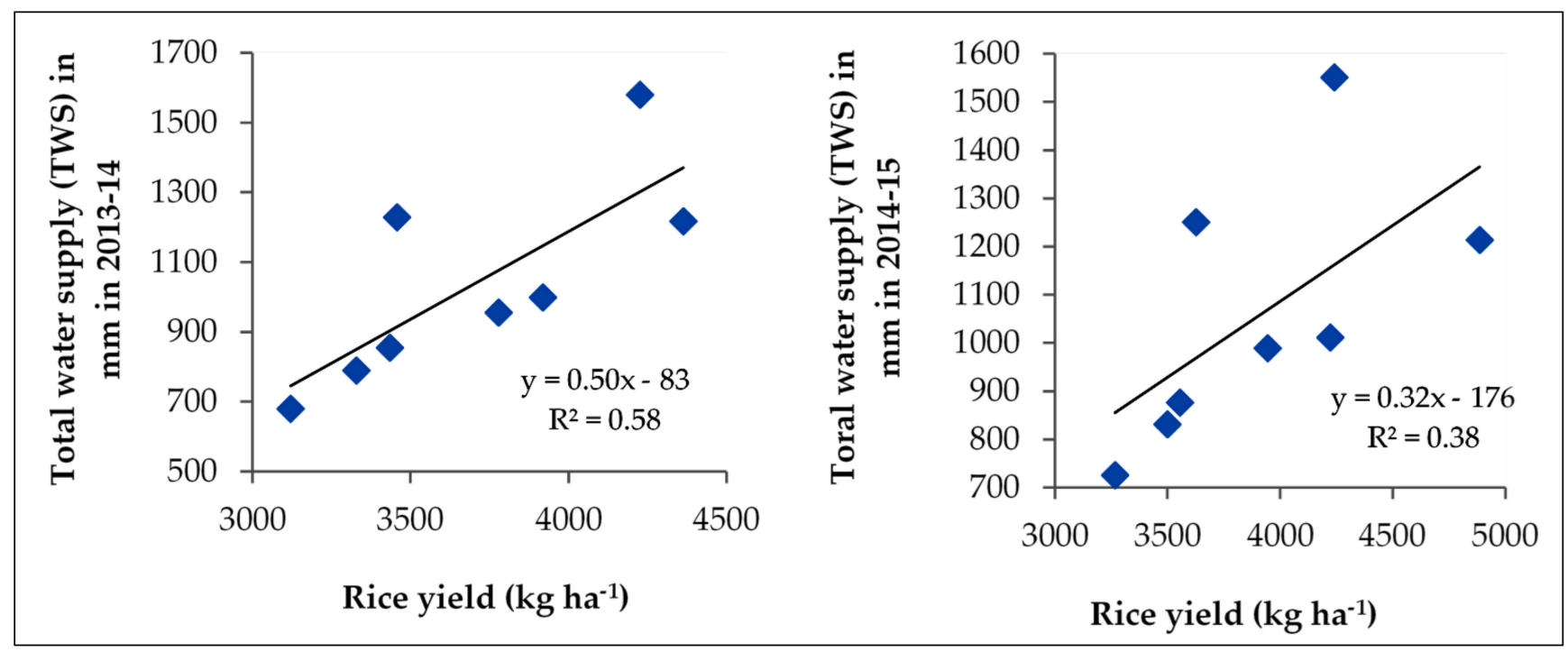

Figure 5. Relation between total water supply (TWS) and yield of rice.

\section{Conclusions}

From this study, it may be concluded that water productivity of okra and summer rice grown in raised and sunken bed (RSB) system has been increased by two times and saved precious underground irrigation water by $40-45 \%$ as compared to traditional rice cultivation. In respect of system water savings and enhancing crop water productivity, the land configuration of RSB (3:3) is very much effective for growing rice + vegetables simultaneously in tube well-irrigated ecosystem during the summer season in the IndoGangetic plains region. Growing of arable okra vegetables in the raised bed and wet crops like rice in the sunken bed will save aquifer water in the tube well commands where ever depleting ground-water aquifer are predominant. Hence, an attempt was made to find out crop diversification and water-saving techniques for higher productivity, i.e., 'more crop per drop' or 'more food with less water'. From this study, it can be concluded that $3 \mathrm{~m}$ sunken rice bed with $3 \mathrm{~m}$ raised okra bed along with alternate wetting and drying irrigation system is the best concerning system productivity of summer rice + okra system and water productivity. The possible risk for this research is faulty land configuration, which may reduce the productivity of the crops. So, the land configuration is one of the most important concerns for the RSB system.

Author Contributions: Conceptualization, P.D., B.P. and S.B.G.; methodology, P.D., B.P. and S.B.G.; software, P.D., B.P., A.H. and S.B.G.; validation, P.D., B.P. and S.B.G.; formal analysis, P.D., A.H., A.M.L. and B.P.; investigation, resources, P.D., B.P. and S.B.G.; data curation, P.D., B.P., A.H., A.M.L., S.M. and S.B.G.; writing-original draft preparation, P.D., B.P. and S.B.G.; writing-review and editing; A.H., A.M.L., S.M. and S.M.I.; visualization, supervision, P.D., B.P. and S.B.G.; project administration, P.D., B.P., S.B.G. and S.M.I.; funding acquisition, A.H. and S.M.I. All authors have read and agreed to the published version of the manuscript.

Funding: The current work was funded by King Saud University Researchers Supporting Project number (RSP-2021/100), King Saud University, Riyadh, Saudi Arabia.

Institutional Review Board Statement: Not applicable.

Informed Consent Statement: Not applicable. 
Data Availability Statement: Data recorded in the current study are available in all Tables and Figures of the manuscript.

Acknowledgments: Authors are grateful to the All India Co-ordinated Research Project on Water Management, BCKV, Gayeshpur, Nadia, WB, India for guiding field works and providing laboratory facilities to conduct the research. The authors also extend their appreciation to King Saud University Re-searchers Supporting Project number (RSP-2021/100), King Saud University, Riyadh, Saudi Ara-bia.

Conflicts of Interest: The authors declare no conflict of interest.

\section{References}

1. Seck, P.A.; Diagne, A.; Mohanty, S.; Wopereis, M.C.S. Crops that feed the world 7: Rice. Food Secur. 2012, 4, 7-24. [CrossRef]

2. Pramanick, B.; Brahmachari, K.; Kar, S.; Mahapatra, B.S. Can foliar application of seaweed sap improve the quality of rice grown under rice-potato-greengram crop sequence with better efficiency of the system? Environ. Boil. Fishes 2020, 32, 1-10. [CrossRef]

3. Suriyan, C.; Yoo, Y.S.; Supaibulneatana, K. Water deficit stress in the productive stage of four indica rice (Oryza sativa L.) genotypes. Pak. J. Bot. 2010, 42, 3387-3398.

4. Gowda, V.R.; Henry, A.; Yamauchi, A.; Shashidhar, H.; Serraj, R. Root biology and genetic improvement for drought avoidance in rice. Field Crop. Res. 2011, 122, 1-13. [CrossRef]

5. Passioura, J. The drought environment: Physical, biological and agricultural perspectives. J. Exp. Bot. 2007, 58, 113-117. [CrossRef] [PubMed]

6. Singh, S.P.; Mahapatra, B.; Pramanick, B.; Yadav, V.R. Effect of irrigation levels, planting methods and mulching on nutrient uptake, yield, quality, water and fertilizer productivity of field mustard (Brassica rapa L.) under sandy loam soil. Agric. Water Manag. 2021, 244, 106539. [CrossRef]

7. Tao, H.; Brueck, H.; Dittert, K.; Kreye, C.; Lin, S.; Sattelmacher, B. Growth and yield formation of rice (Oryza sativa L.) in the water-saving ground cover rice production system (GCRPS). Field Crop. Res. 2006, 95, 1-12. [CrossRef]

8. Yang, J.-C.; Liu, K.; Zhang, S.-F.; Wang, X.-M.; Wang, Z.-Q.; Liu, L.-J. Hormones in Rice Spikelets in Responses to Water Stress During Meiosis. ActaAgron. Sin. 2008, 34, 111-118. [CrossRef]

9. FAO. (FAOSTAT Production); Food and Agriculture Organization of the United Nations (FAO): Rome, Italy, 2008.

10. Ghosh, P.K.; Saha, R.; Das, A.; Tripathi, A.K.; Samuel, M.P.; Lama, T.D.; Mandal, S.; Ngachan, S.V. Participatory Rain Water Management in Hill Ecosystem-A Success Story; Technical bulletinno; 67.FPARP-Phase I; ICAR Research Complex for NEH Region: Meghalaya, India, 2009; p. 37.

11. Goswami, S.B.; Sarkar, S. Effect of irrigation on crop water productivity of pointed gourd (Trichosanthes dioica) at varying bed width planting system. Ind. J. Agric. Sc. 2007, 77, 340-343.

12. Sharma, P.K. Raised-sunken bed system for increasing productivity of rice-based cropping system in high rainfall areas of Himachal Pradesh. J. Indian Soc. Soil Sci. 2003, 51, 10-16.

13. Molden, D.; Rijsberman, F.; Matsuno, Y.; Amarasinghe, U. Increasing Water Productivity: A Requirement for Food and Environmental Security. In Proceedings of the Global Dialogue on Food and Environmental Security, Colombo, Sri Lanka, 2000. Available online: http:/ / www.iwmi.cgiar.org/About_IWMI/Strategic_Documents / Annual_Reports/2001_2002/AnnualReport2001200 2.pdf (accessed on 13 September 2021).

14. Amarasingha, R.; Suriyagoda, L.; Marambe, B.; Rathnayake, W.; Gaydon, D.; Galagedara, L.; Punyawardena, R.; Silva, G.; Nidumolu, U.; Howden, M. Improving water productivity in moisture-limited rice-based cropping systems through incorporation of maize and mungbean: A modelling approach. Agric. Water Manag. 2017, 189, 111-122. [CrossRef]

15. Pereira, L.S. Relating water productivity and crop evapotranspiration. In Proceedings of the Water Use Efficiency and Water Productivity, Amman, Jordan, 2005; pp. 31-49. Available online: https://www.nap.edu/read/25059/chapter/8 (accessed on 13 September 2021).

16. Kijne, J.; Barker, R.; Molden, D. Improving Water Productivity in Agriculture: Editors' Overview. In Water Productivity in Agriculture: Limits and Opportunities for Improvement, Comprehensive Assessment of Water Management in Agriculture; Kijne, J., Ed.; CABI Publishing in Association with International Water Management Institute: Wallingford, UK, 2003; p. 199.

17. Reddy, S.R. Principles of Agronomy; Kalyani Publishers: New Delhi, India, 2010; pp. 309-310.

18. Gomez, K.A.; Gomez, A.A. Statistical Procedures for Agricultural Research, 2nd ed.; John Wiley \& Sons: New York, NY, USA, 1984.

19. Li, Y.; Barker, R. Increasing water productivity for paddy irrigation in China. Paddy Water Environ. 2004, 2, 187-193. [CrossRef]

20. Singh, C.B.; Aujla, T.S.; Sandhu, B.S.; Khera, K.L. Effects of transplanting data and irrigation regime on growth, yield and water use in rice (Oryza sativa) in northern India. Indian J. Agric. Sci. 1996, 66, 137-141.

21. Singh, R.; Kundu, D.K.; Kannan, K.; Thakur, A.K.; Mohanty, R.K.; Kumar, A. Technologies for Improving Farm Level Water Productivity in Canal Commands; Research Bulletin No. 43; Water Technology Centre for Eastern region (Indian council of Agricultural Research): Bhubaneswar, India, 2008; p. 56.

22. Aslam, M.; Prathapar, S.A. Water Management in the Rice-Wheat Cropping Zone of Sindh, Pakistan: A Case Study. In The Rice-Wheat Cropping System of South Asia: Efficient Production Management; CRC Press: Boca Raton, FL, USA, 2021 ; pp. $249-272$. 
23. Murthy, K.M.; Reddy, D.; Rao, C.V.; Upendra, A.; Zaheruddeen, S.M. Water management and varietal response of rice under System of Rice Intensification (SRI) in Godavari delta of Andhra Pradesh. In Proceedings of the National Symposium on System of Rice Intensification (SRI)-Present Status and Future PROSPECTS, Hyderabad, India, 17-18 November 2006 ; p. 98.

24. Jat, H.S.; Singh, G.; Singh, R.; A Choudhary, M.; Jat, M.L.; Gathala, M.K.; Sharma, D.K. Management influence on maize-wheat system performance, water productivity and soil biology. Soil Use Manag. 2015, 31, 534-543. [CrossRef]

25. Saha, R.; Ghosh, P.K. Effect of land configuration on water economy, crop yield and profitability under rice (Oryza sativa)-based cropping systems in north-east India. Indian J. Agric. Sci. 2010, 80, 16-20.

26. Das, A.; Layek, J.; Ramkrushna, G.I.; Patel, D.P.; Choudhury, B.U.; Chowdhury, S.; Ngachan, S.V. Raised and sunken bed land configuration for crop diversification and crop and water productivity enhancement in rice paddies of the north eastern region of India. Paddy Water Environ. 2015, 13, 571-580. [CrossRef]

27. Moya, P.; Hong, L.; Daweand, D.; Chen, C.D. Comparative assessment of on-farm water-saving irrigation techniques in the Zhanghe Irrigation System. In Proceedings of the International Conference on Environmentally Sound Water Resources Utilization, Bangkok, Thailand, 2001; International Water Management Institute: Colombo, Sri Lanka, 2001; pp. 81-96.

28. Belder, P.; Bouman, B.; Cabangon, R.; Guoan, L.; Quilang, E.; Yuanhua, L.; Spiertz, J.; Tuong, T. Effect of water-saving irrigation on rice yield and water use in typical lowland conditions in Asia. Agric. Water Manag. 2004, 65, 193-210. [CrossRef]

29. Alliaume, F.; Rossing, W.; Tittonell, P.; Jorge, G.; Dogliotti, S. Reduced tillage and cover crops improve water capture and reduce erosion of fine textured soils in raised bed tomato systems. Agric. Ecosyst. Environ. 2014, 183, 127-137. [CrossRef] 